\title{
Dietary strategies for achieving adequate vitamin $D$ and iron intakes in Irish pre-school children aged 1-4 years
}

\author{
L. Kehoe ${ }^{1}$, J. Walton ${ }^{1}$, B.A. McNulty ${ }^{2}$, A.P. Nugent ${ }^{2}$ and A. Flynn ${ }^{1}$ \\ ${ }^{1}$ School of Food and Nutritional Sciences, University College Cork, Republic of Ireland and ${ }^{2}$ UCD Institute of Food \\ and Health, University College Dublin, Belfield, Dublin 4, Republic of Ireland
}

This abstract was awarded the student prize for best poster original communication.

Irish children have low intakes of vitamin D and iron and the main difference in intakes between high and low consumers of vitamin $\mathrm{D}$ and iron is attributable to fortified foods and nutritional supplements ${ }^{(1,2)}$. The objective of this study was to model the potential impact of a number of fortification/supplementation scenarios on vitamin D and iron adequacy in 1 to 4 year old children based on food consumption (4-day food diary) and composition data (UK and Irish Food Composition Tables) from the National Pre-School Nutrition Survey (NPNS) (2010-2011) (www.iuna.net). Five main simulation scenarios were investigated using DaDiet ${ }^{\mathbb{O}}$ Version 15.05: 1) Addition of a $5 \mu \mathrm{g} / \mathrm{d}$ vitamin D supplement, 2) Fortification of all cows' milk (CM) with $2 \mu \mathrm{g}$ vitamin D/100 ml, 3) Replacing CM with growing-up milks (GUM) (1 \& 2 year olds only), 4) Fortification of all CM plus a 5 $\mu$ g/d vitamin D supplement and 5) Replacing all CM with GUM plus a $5 \mu \mathrm{g} / \mathrm{d}$ vitamin D supplement. Usual intakes of vitamin D and iron were calculated via the NCI-method ${ }^{(3)}$ using SAS $^{\complement}$ Enterprise Guide.

Table 1. Proportion (\%) with intakes of vitamin D below the EAR at baseline \& for scenarios $1,2,3 \& 4$

\begin{tabular}{|c|c|c|c|c|c|c|}
\hline Age & Baseline & $\begin{array}{l}5 \mu \mathrm{g} / \mathrm{d} \text { vitamin } \\
\mathrm{D} \text { supplement }\end{array}$ & $\begin{array}{l}\text { Vitamin D Fortified } \\
\mathrm{CM}(2 \mu \mathrm{g} / 100 \mathrm{ml})\end{array}$ & $\begin{array}{l}\text { Replace CM } \\
\text { with GUM }\end{array}$ & $\begin{array}{l}\text { Vitamin D Fortified } \\
\text { CM \& vitamin D } \\
\text { supplement }\end{array}$ & $\begin{array}{l}\text { Replace CM with } \\
\text { GUM \& vitamin } \\
\text { D supplement }\end{array}$ \\
\hline \multicolumn{7}{|c|}{$\%<\operatorname{EAR}(10 \mu \mathrm{g} / \mathrm{d})$} \\
\hline $\begin{array}{l}\text { year olds } \\
\text { (12-23 months) }\end{array}$ & $95 \cdot 4$ & $75 \cdot 9$ & $55 \cdot 3$ & 24.9 & $12 \cdot 4$ & $4 \cdot 7$ \\
\hline $\begin{array}{l}2 \text { year olds } \\
(24-35 \text { months })\end{array}$ & $97 \cdot 1$ & $86 \cdot 7$ & $67 \cdot 9$ & $39 \cdot 0$ & $23 \cdot 5$ & 11.5 \\
\hline $\begin{array}{l}3 \text { year olds } \\
\text { (36-47 months) }\end{array}$ & $97 \cdot 4$ & $91 \cdot 3$ & $76 \cdot 8$ & - & $35 \cdot 4$ & - \\
\hline $\begin{array}{l}4 \text { year olds } \\
(48-59 \text { months) }\end{array}$ & $97 \cdot 2$ & $89 \cdot 1$ & $79 \cdot 1$ & - & $36 \cdot 4$ & - \\
\hline
\end{tabular}

Table 2. Proportion (\%) with intakes of iron below the EAR at baseline \& for scenario 5 .

\begin{tabular}{lcc}
\hline Age & Baseline & Replacing CM with GUM \\
\hline & $\%<$ EAR $(5 \mathrm{mg} / \mathrm{d})$ & \\
\hline year olds (12-23 months) & $13 \cdot 7$ & $0 \cdot 7$ \\
2 year olds (24-35 months) & $7 \cdot 1$ & $0 \cdot 3$ \\
\hline
\end{tabular}

At baseline $95-97 \%$ of children had intakes of vitamin D below the estimated average requirement (EAR) of $10 \mu \mathrm{g} / \mathrm{d}^{(4)}$ while $14 \%$ of 1 year olds and $7 \%$ of 2 year olds had iron intakes below the EAR of $5 \mathrm{mg} / \mathrm{d}^{(5)}$. For vitamin D, the addition of a $5 \mu \mathrm{g} / \mathrm{d}$ supplement to the diets of all children aged 1 to 4 years would result in a modest reduction in the prevalence of inadequate intakes (to 76-91\%). The fortification of CM with vitamin D or replacing all CM with GUM would result in a more substantial reduction in the proportion of the population with inadequate intakes of vitamin D (to 55-79\%) or (to 25-39\%) while the greatest reductions would result from a combination of a vitamin D supplement and vitamin D fortified CM (to 12-36\%) or a vitamin D supplement and replacement of CM with GUM (to 5-12\%). For iron, replacing CM with GUM would reduce the proportion of 1 and 2 year old children with inadequate intakes to $<1 \%$. These analyses provide valuable information that will aid in the development of dietary strategies to improve intakes of vitamin D and iron in Irish pre-school children.

The project was funded by the Irish Department of Agriculture, Food and the Marine under the Nutridata Project 13 F 542; $2014-2016$.

1. Kehoe L, Walton J, McNulty B et al. (2015) Proc Nutr Soc 74, (OCE4):E219.

2. Kehoe L, Walton J, McNulty B et al. (2015) Ann Nutr Metab 67, (Suppl. 1):149/449.

3. Tooze JA, Kipnis V, Buckman DW et al. (2010) Stat Med 29, (27):2857-2868

4. IOM (2011) National Academies Press. Washington DC.

5. EFSA (2015) EFSA $J$ 13, (10):4254. 